\title{
Peningkatan Kemampuan Literasi dan Numerasi Peserta Didik Melalui Program Kampus Mengajar Angkatan 2
}

\author{
Bagus Ali Rachman*1, Firyalita Sarah Fidaus², Nurul Lailatul Mufidah³, Halimatus Sadiyah", \\ Ifit Novita Sari*5 \\ 1,2,3Program Studi Pendidikan Guru Sekolah Dasar, Fakultas Psikologi dan Ilmu Pendidikan, Universitas \\ Muhammadiyah Sidoarjo \\ 4Program Studi Psikologi, Fakultas Psikologi dan Ilmu Pendidikan, Universitas Muhammadiyah Sidoarjo \\ ${ }^{5}$ Program Studi Pendidikan Bahasa dan Sastra Indonesia, Fakultas Keguruan dan Ilmu Pendidikan, \\ Universitas Islam Malang \\ *e-mail: bagusrachman30@gmail.com¹, nurullalatulmufidah11@gmai.com², firyalitakiming@gmail.com³, \\ lilysadiyah455@gmail.com ${ }^{4}$,inovsari@unisma.ac.id ${ }^{5}$
}

\begin{abstract}
This service is motivated by the activities of Campus Teaching 2 which is a form of implementation of the Merdeka Learning Campus Merdeka (MBKM) program from the Ministry of Education, Culture, Research and Technology. This program is based on the ineffectiveness of the implementation of learning carried out during the Covid-19 pandemic. This can be seen from the decline in students' interest in learning, the level of understanding of students when learning, and the literacy and numeracy abilities of students. Based on these problems affect the effectiveness of the learning process, one of which is in SMP Negeri 2 Tanggulangin. One of the methods used in the service is literacy and numeracy habituation activities. The final result of this activity is the habituation of literacy and numeracy for students at SMP Negeri 2 Tanggulangin and increasing the real role and contribution of higher education institutions and students in national development.
\end{abstract}

Keywords: Campus Teaching, Literacy, and Numeration

\begin{abstract}
Abstrak
Pengabdian ini dilatarbelakangi oleh kegiatan Kampus Mengajar 2 yang merupakan bentuk pelaksanaan program Merdeka Belajar Kampus Merdeka (MBKM) dari Kementerian Pendidikan Kebudayaan Riset dan Teknologi. Program ini didasari atas kurang efektifnya pelaksanaan pembelajaran yang dilaksanakan di masa pandemi Covid-19. Hal tersebut terlihat dari menurunnya minat belajar peserta didik, tingkat pemahaman peserta didik ketika pembelajaran, dan kemampuan literasi dan numerasi peserta didik. Berdasarkan permasalahan tersebut mempengaruhi efektivitas proses pembelajaran, salah satunya di SMP Negeri 2 Tanggulangin. Metode yang digunakan pada pengabdian salah satunya berupa kegiatan pembiasaan literasi dan numerasi. Hasil akhir dari kegiatan ini berupa pembiasaan literasi dan numerasi untuk peserta didik-siswi di SMP Negeri 2 Tanggulangin serta meningkatkan peran dan kontribusi nyata perguruan tinggi dan mahapeserta didik dalam pembangunan nasional.
\end{abstract}

Kata kunci: Kampus Mengajar, Literasi, dan Numerasi

\section{PENDAHULUAN}

Rendahnya minat baca masyarakat kita sangat mempengaruhi kualitas bangsa Indonesia. Rendahnya minat baca menyebabkan kita tidak dapat mengikuti perkembangan ilmu pengetahuan dan informasi di dunia, di mana pada akhirnya akan berdampak pada ketertinggalan bangsa Indonesia. Budaya membaca di Negara maju sudah menjadi kebutuhan mutlak dalam kehidupan sehari harinya. Oleh karena itu kita perlu meniru upaya yang dilakukan Negara maju yaitu dengan cara menumbuhkan minat baca sejak dini baik disekolah dasar, menengah, maupun atas. Serta menerapakannya pada kehidupan sehari-hari.

Literasi merupakan salah satu program prioritas pemerintah untuk tahun 2019. Kemampuan literasi dinilai berperan penting bagi pertumbuhan intelektual dan kompetisi setiap individu di Indonesia. Gerakan Literasi Sekolah (GLS) sebenarnya telah digalakan sejak tahun 2015 sejalan dengan penerbitan Peraturan Menteri Pendidikan dan Kebudayaan Nomor 23 Tahun 2015 tentang Penumbuhan Budi Pekerti. Demi menyukseskan pembangunan Indonesia di abad ke-21, menjadi keharusan bagi masyarakat Indonesia atau instansi pendidikan untuk menguasai 
enam literasi dasar, yaitu: literasi bahasa, literasi numerasi, literasi sains, literasi digital, literasi finansial, serta literasi budaya dan kewargaan. Kemampuan literasi ini juga harus diimbangi dengan menumbuhkembangkan kompetensi yang meliputi kemampuan berpikir kritis/ memecahkan masalah, kreativitas, komunikasi, dan kolaborasi.

Kementerian Pendidikan Kebudayaan Riset dan Teknologi meluncurkan program Merdeka Belajar Kampus Merdeka memberikan kesempatan bagi para mahapeserta didik dan mahasiswi di seluruh Indonesia untuk mengembangkan kemampuannya sesuai bakat dan minat masing-masing. Perlu pengembangan metode pembelajaran yang menarik minat dan bakat mahasiswa untuk lebih berkarya (Putri, 2018). Mahapeserta didik hadir sebagai partner guru dalam melakukan kreativitas dan inovasi pembelajaran. Rahmah dan Triristina (2021) mengungkapkanbahwa Kampus Mengajar melibatkan mahapeserta didik di setiap kampus dari berbagai latar belakang pendidikan untuk membantu proses belajar mengajar di sekolah. program pengabdian kepada masayarakat dengan program Kampus Mengajar yang melibatkan seluruh Mahapeserta didik Indonesia guna mensukseskan program Gerakan Literasi Sekolah, serta membantu program pemerintah AKM (Asesmen Kompetensi Minimum). Menurut Rokhim et al (2021) Asesmen Kompetensi Minimum digunakan untuk mengukur hasil belajar kognitif meliputi literasi membaca dan literasi numerasi (matematika) atau bisa juga di sebut pengganti ANBK.

Mitra dalam pengabdian Masyarakat ini adalah SMPN 2 Tanggulangin yang berlokasi di Desa Kedungbanteng Tanggulangin, Sidoarjo. Dimana sekolah tersebut dipilih karna masih memenuhi kriteria 3T yaitu (Terdepan, Terluar, dan Tertinggal). Menurut Syafii (2018) di daerah terutama pada daerah yang tergolong terdepan, terluar dan tertinggal (daerah 3T) masih banyak yang belum mendapatkan pendidikan yang layak. Meskipun demikian sekolah tersebut sudah melaksanakan Gerakan Literasi Sekolah dimana sebelum adanya masa Pandemi Covid-19 peserta didik di wajibkan untuk meminjam buku di perpustakaan sekolah di minta untuk membaca lalu meriviewnya, kegiatan tersebut dilakukan selama 1 kali dalam seminggu.

Namun setelah pembelajaran daring kegiatan tersebut sedikit berhenti dan juga terkendala kurangnya guru yang faham dengan media teknologi digital. Oleh karena itu mahasiswa Kampus Mengajar 2 ingin menghidupkan kembali gerakan literasi sekolah tersebut dengan membuat suatu kegiatan pembiasaan literasi dan numerasi kepada peserta didik. Dalam kegiatan ini, nantinya peserta didik mengerjakan soal-soal berbasis AKM yang terdiri dari soalsoal literasi dan soal-soal numerasi.

\section{METODE}

Kegiatan pengabdian Kampus Mengajar Angkatan 2 ini yang dilaksanakan oleh mahasiswa dan juga Dosen pembimbing Lapangan (DPL) yang bertempat di SMP Negeri 2 Tanggulangin yang salah satu tujuannya untuk membantu pembelajaran literasi dan numerasi dan meningkatkan dan menumbuhkan minat baca peserta didik. Pelaksanaan kegiatan ini dimulai sejak tanggal 11 Oktober 2021 sampai dengan 8 november 2021 yang diikuti oleh seluruh peserta didik kelas 7,8 dan 9 SMP Negeri 2 Tanggulangin. Kegiatan ini dilaksanakan dengan metode yang bertahap, yakni tahap rencana kegiatan, tahap pelaksanaan kegiatan, dan tahap perbaikan dan tindak lanjut.

Tabel 1. Tahapan Metode Kegiatan Pengabdian

\begin{tabular}{lll}
\hline No $\quad$ Tahapan pengabdian & \multicolumn{1}{c}{ Kegiatan pengabdian } \\
\hline 1. $\quad$ Tahap I & 1. $\begin{array}{l}\text { Observasi, mengamati kondisi lingkungan sekolah serta } \\
\text { partisipasi warga sekolah dalam kegiatan literasi dan } \\
\text { nuumerasi. }\end{array}$ \\
& 2. $\begin{array}{l}\text { Berkoordinasi bersama pihak sekolah terkait pelaksanaan } \\
\text { literasi yang sudah dilaksanakan sebelumnya. }\end{array}$ \\
\hline
\end{tabular}




\begin{tabular}{lll}
\hline 2. Tahap II & 1. & $\begin{array}{l}\text { Pembuatan media untuk kegiatan literasi dan numerasi, } \\
\text { dengan tujuan dapat menarik perhatian peserta didik dalam } \\
\text { literasi dan numerasi. }\end{array}$ \\
& 2. $\begin{array}{l}\text { Sosialisasi program kegiatan literasi dan numerasi kepada } \\
\text { peserta didik. }\end{array}$ \\
3. $\begin{array}{l}\text { Pengumpulan hasil kegiatan literasi dan numerasi oleh } \\
\text { peserta didik. }\end{array}$ \\
3. Tahap III \\
Evaluasi
\end{tabular}

\section{HASIL DAN PEMBAHASAN}

Pengabdian kepada masyarakat ini dilakukakan diikuti oleh seluruh siswa di SMP Negeri 2 Tanggulangin. Kegiatan pengabdian masyarakat ini, diawali dengan menyampaikan program kegiatan pembiasaan literasi dan numerasi yang akan dilaksanakan di SMP Negeri 2 Tanggulangin. Kemudian dilanjutkan dengan diskusi bersama guru-guru tentang pelaksanaan kegiatan literasi yang sudah pernah di laksanakan di SMP Negeri 2 Tanggulangin, sebagaimana pada gambar 1. Dari diskusi tersebut, diketahui bahwa pelaksanaan kegiatan literasi di SMP Negeri 2 Tanggulangin hanya sekedar merangkum atau meresume buku-buku dari perpustakaan saja. Kegiatan tersebut terakhir dilaksanakan ketika sebelum masa pandemi Covid-19, artinya kegiatan tersebut sudah lama tidak aktif lagi.

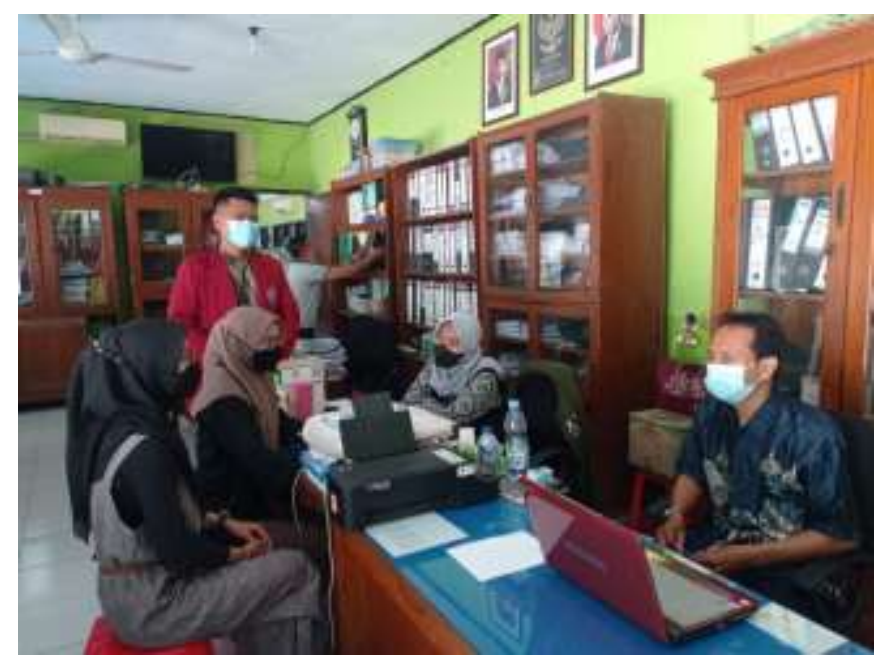

Gambar 1. Berkoordinasi dengan guru terkait program literasi dan numerasi

Berdasarkan dari hasil diskusi dengan guru-guru tentang pelaksanaan kegiatan literasi, mahasiswa Kampus Mengajar 2 berinisiatif untuk menghidupkan lagi kegiatan litarasi di SMP Negeri 2 Tanggulangin. Namun dalam pelaksanaannya sedikit berbeda dengan kegiatan literasi sebelumnya. Kegiatan yang akan dilaksanakan ini menggunakan soal-soal berbasis AKM (Asesmen Kompetensi Minimum) yang terbagi menjadi 2 kegiatan yaitu literasi dan numerasi. Menurut Rokhim et al., (2021) Asesmen Kompetensi Minimum digunakan untuk mengukur hasil belajar kognitif meliputi literasi membaca dan literasi numerasi (matematika). Berdasarkan pernyataan tersebut, kegiatan ini lebih berfokus pada peningkatan kemampuan literasi dan numerasi pada siswa-siswa di SMP Negeri 2 Tanggulangin.

Sebelum melaksanakan kegiatan ini, mahasiswa Kampus Mengajar 2 menyiapkan media yang digunakan terlebih dahulu untuk kegiatan literasi dan numerasi di SMP Negeri 2 Tanggulangin, sebagaimana pada gambar 2 . 


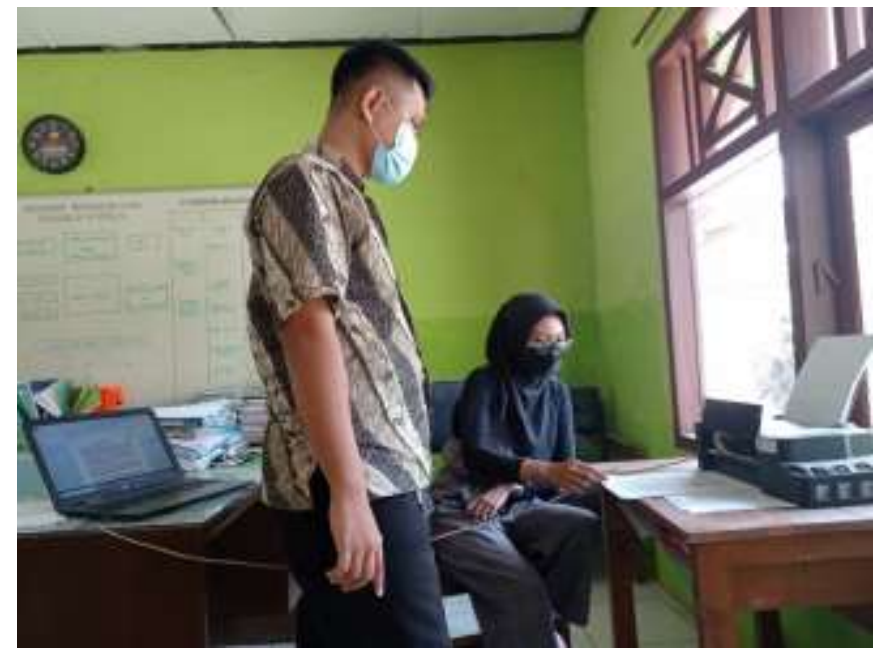

Gambar 2. Menyiapkan media literasi

Dalam pelaksanaan kegiatan ini, pada tanggal 11 Oktober 2021 mahasiswa Kampus Mengajar 2 bersama dengan guru mensosialisasikan terlebih dahulu kepada siswa mewakili kelasnya masing-masing tentang pelaksanaan program kegiatan literasi dan numerasi tersebut, sebagaimana terlihat pada gambar 3. Program kegitan literasi dan numerasi ini dilaksanakan siswa seminggu sekali untuk setiap sesinya, hal ini dikarenakan pelaksanaan pembelajaran di SMP Negeri 2 Tanggulangin masih memberlakukan Pembelajaran Tatap Muka Terbatas yang terbagi menjadi 2 sesi setiap minggunya yakni sesi 1 untuk siswa absen 1-16 dan sesi 2 untuk absen 1732. Dalam pengumpulan hasil kegiatan literasi dan numerasi ini, siswa mengumpulkannya secara langsung kepada mahasiswa Kampus Mengajar 2, seperti pada gambar 4.

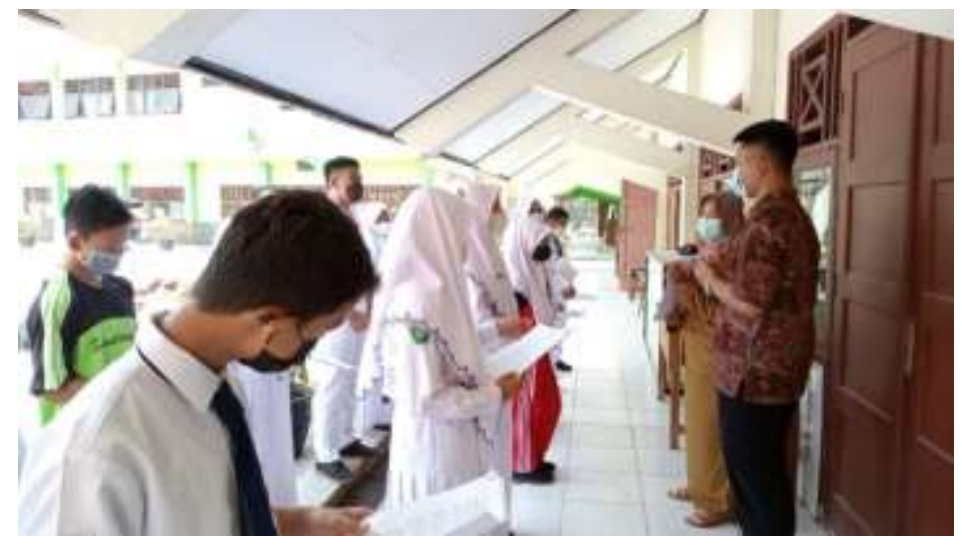

Gambar 3. Sosialisasi program kegiatan literasi dan numerasi kepada siswa

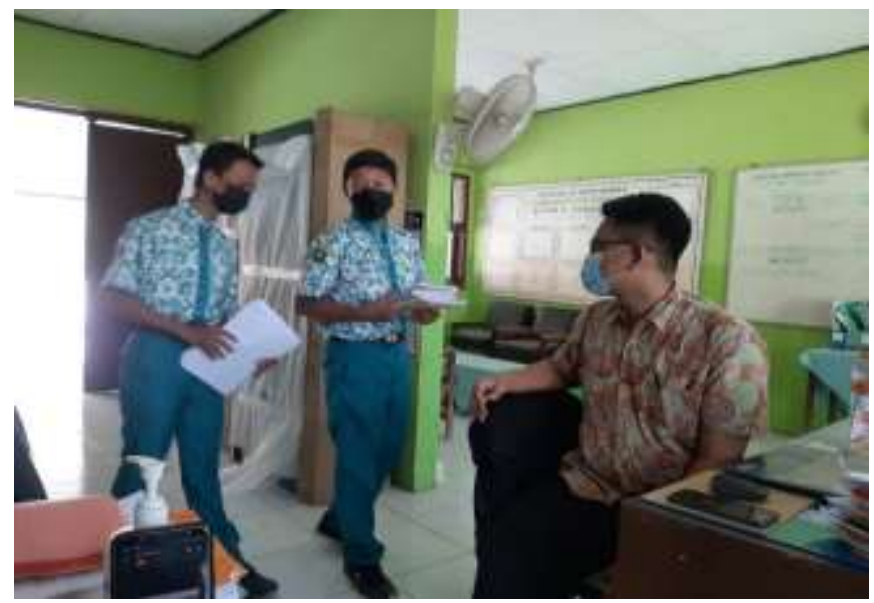

Gambar 4. Pengumpulan hasil kegiatan literasi dan numerasi oleh siswa 
Dalam penilaian hasil dari kegiatan literasi dan numerasi ini, mahasiswa Kampus Mengajar 2 menilai dari hasil jawaban setiap siswa, sebagaimana terlihat pada gambar 5 . Tujuan dari penilaian ini yaitu untuk mengukur tingkat kemampuan literasi dan numerasi siswa di SMP Negeri 2 Tanggulangin.
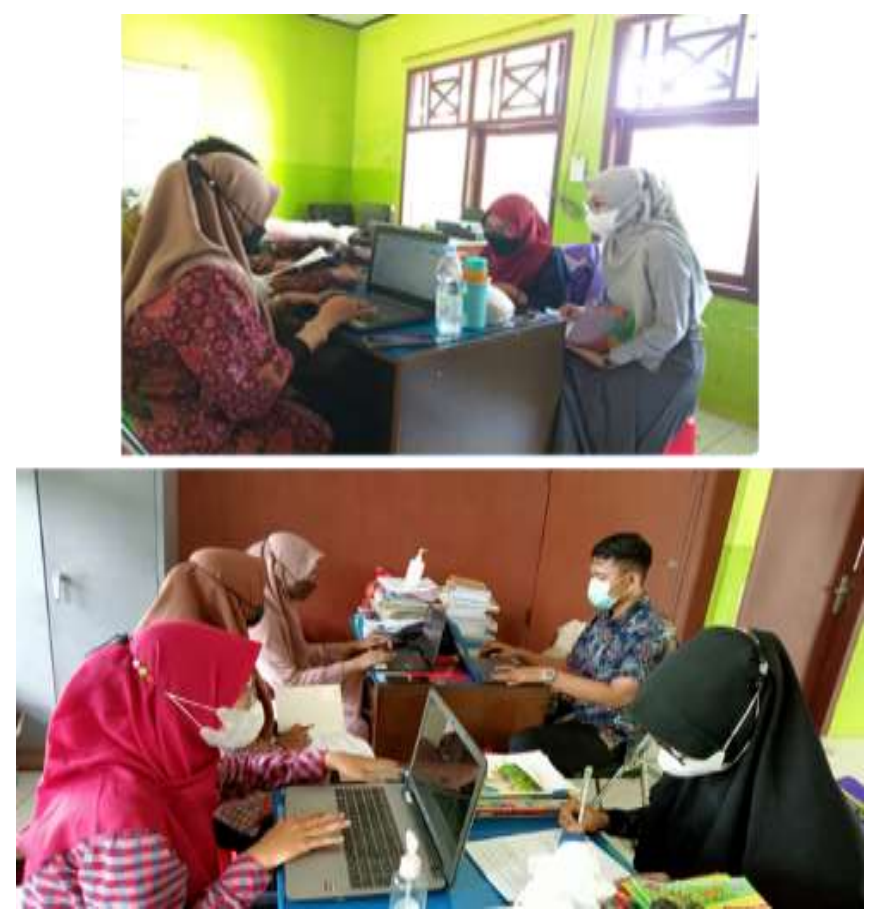

Gambar 5. Penilaian hasil kegiatan literasi dan numerasi siswa

Dari hasil penilaian kegiatan literasi dan numerasi ini, mahasiswa Kampus Mengajar 2 melakukan evaluasi kegiatan dan menentukan daftar nama siswa yang aktif dalam kegiatan ini dan memiliki tingkat kemampuan literasi dan numerasi tinggi dari setiap jenjang kelas, sebagaimana terlihat pada gambar 6. Setelah itu, mahasiswa Kampus Mengajar 2 membagikan hadiah kepada siswa-siswi ketika pelaksanaan Apel pagi pada hari Senin, 8 November 2021, sebagaimana terlihat pada gambar 7 .

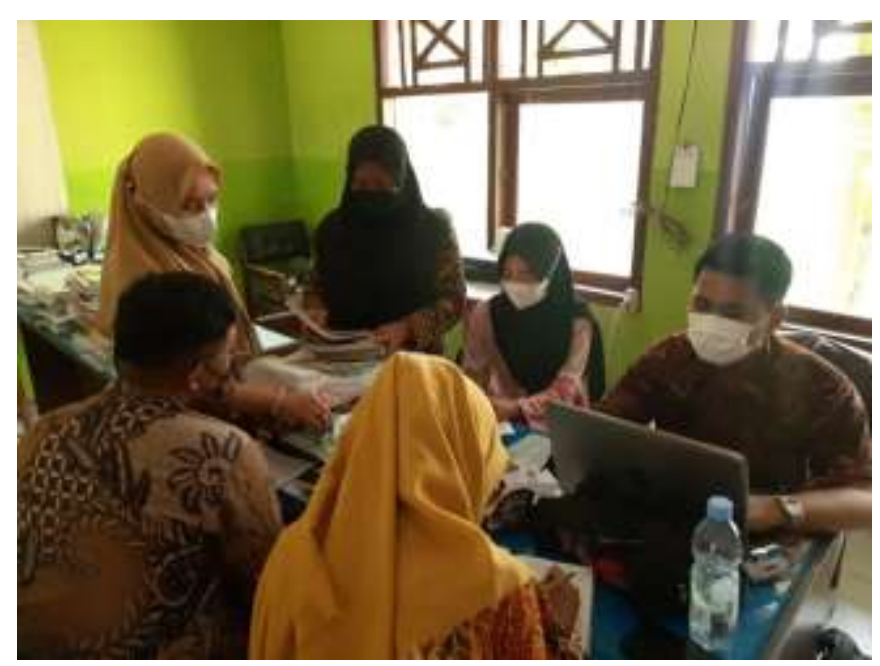

Gambar 6. Evaluasi kegiatan literasi dan numerasi 


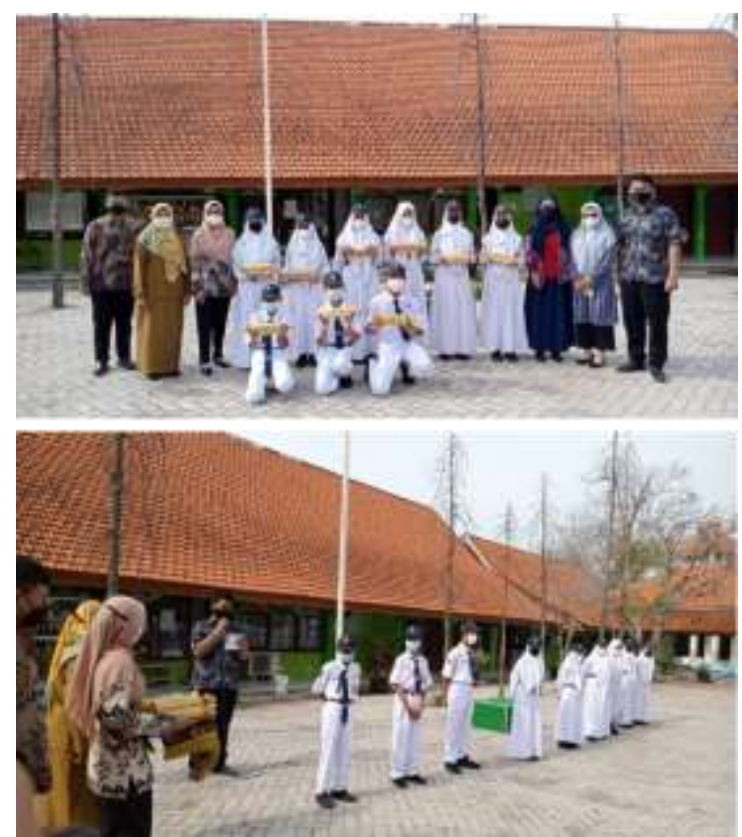

Gambar 7. Pembagian hadiah kepada siswa yang aktif dalam kegiatan dan memiliki tingkat kemampuan literasi dan numerasi tinggi

Manfaat dari kegiatan pembiasaan literasi dan numerasi ini antara lain: (1) siswa terbiasa dengan soal-soal berbasi AKM; (2) kemampuan literasi dan numerasi siswa meningkat; (3) budaya literasi dan numerasi di SMP Negeri 2 Tanggulangin aktif kembali.

\section{KESIMPULAN}

Kegiatan pengabdian kepada masyarakat melalui program Kampus Mengajar ini telah memberikan pengalaman langsung bagi mahasiswa tentang proses pembelajaran sesungguhnya di sekolah. Kegiatan pengabdian kepada masyarakat ini bertujuan membantu guru dan siswa di SMPN 2 Tanggulangin dalam meningkatkan kemampuan literasi dan numerasi siswa menjadi lebih baik.

Hasil dari kegiatan pengabdian ini diharapkan dapat memberikan perspektif kepada generasi muda, khususnya mahasiswa lainnya untuk dapat melakukan hal serupa, yaitu pengabdian kepada masyarakat dengan cara membantu peserta didik yang kekurangan sarana prasarana dalam melakukan kegiatan pembelajaran di era pandemi.

\section{UCAPAN TERIMA KASIH}

Terima kasih kepada Kementerian Pendidikan dan Kebudayaan Riset dan Teknologi Republik Indonesia yang telah menyelenggarakan program Kampus Mengajar dan kepada pihak SMP Negeri 2 Tanggulangin yang telah mendukung program-program yang dilaksanakan oleh mahasiswa Kampus Mengajar 2 di SMP Negeri 2 Tanggulangin.

\section{DAFTAR PUSTAKA}

Hikmawati, Sari, K. I. W., Malkan, M., Andani, T. G., and Habibah, F. N. (2021). Pengembangan Literasi Digital Guru dan Siswa Melalui Program Kampus Mengajar di SMPN 19 Mataram. Unram Journal of Community Service, 2(3), 83-88. 
Khotimah, N. R., Riswanto, and Udayati. (2021). Pelaksanaan Program Kampus Mengajar di SD Negeri 014 Palembang Sumatera Selatan. Jurnal Sinar Sang Surya, 5(2), 194-204.

Lestari, P. W., Izzah, H. N., and Yudyaningtyas, M. K. (2020). Peningkatan Minat Baca dengan Program Generasi Masyarakat Gemar Membaca di RPTRA Cililitan Jakarta Timur. Dinamisia : Jurnal Pengabdian Kepada Masyarakat, 5(1), 106-111.

Nurhasanah, A. D., and Nopianti, H. (2020). Peran Mahasiswa Program Kampus Mengajar Dalam Meningkatkan Kompetensi SDN 48 Bengkulu Tengah. SNPKM: Seminar Nasional Pengabdian Kepada Masyarakat, 3, 166-173.

Putera, M. T., and Rhussary, M. L. (2018). Peningkatan Mutu Pendidikan Daerah 3t (Terdepan, Terpencil dan Tertinggal) di Kabupaten Mahakam Hulu. Jurnal Ekonomi Dan Manajemen, 12(2), 144-148.

Putri, L. D., Repi, \& Fitridawati Soehardi. (2018). Pemberdayaan Mahasiswa Fakultas Teknik Dengan Program Kreatifitas Mahasiswa (PKM). Dinamisia: Jurnal Pengabdian Kepada Masyarakat, 2(2), 315-321. https://doi.org/10.31849/dinamisia.v2i2.1184

Rahmah, A. N. A., and Triristina, N. (2021). Kampus Mengajar : Transformasi Budaya Belajar Siswa dalam Adaptasi Kebiasaan Baru di Madura. NiCMa: National Conference Multidisplinary, 1(1), 34-39.

Rokhim, D. A., Rahayu, B. N., Alfiah, L. N., Peni, R., Wahyudi, B., Wahyudi, A., ... Widarti, H. R. (2021). Analisis Kesiapan Peserta Didik dan Guru pada Asesmen Nasional (Asesmen Kompetensi Minimum, Survey Karakter, dan Survey Lingkungan Belajar). Jurnal Administrasi Dan Manajemen Pendidikan, 4(1), 61.

Suharman, Y., Sejati, S. P., and Pratama, D. A. (2021). Peningkatan Pengetahuan tentang Pembangunan Berkelanjutan Menggunakan Media Cerita Bergambar di Tingkat Sekolah Dasar. Dinamisia: Jurnal Pengabdian Kepada Masyarakat, 5(5), 1232-1239.

Superman, Purmintasari, Y. D., and Agustina, R. (2020). Penguatan Literasi Di Sekolah. GERVASI: Jurnal Pengabdian Kepada Masyarakat, 3(2), 230-240.

Syafii, A. (2018). Perluasan dan Pemerataan Akses Kependidikan Daerah 3T (Terdepan, Terluar, Tertinggal). Dirāsāt: Jurnal Manajemen Dan Pendidikan Islam, 4(2), 153-171. 